ISSN 2616-7328 (Online), ISSN 2409-904X (Print)

Kitaêznavčì doslìdžennâ, 2018, No. 1, pp. 77-82

UDC 327.5:94(510)

doi: https://doi.org/10.15407/chinesest2018.01.077

\title{
CHINA AS A THIRD PARTY IN PEACE PROCESSES IN UKRAINE AND ISRAEL/PALESTINE
}

\author{
Ye. Hobova \\ $\mathrm{PhD}$ (Linguistics), Junior Researcher \\ A. Yu. Krymskyi Institute of Oriental Studies, NAS of Ukraine \\ 4, Hrushevskoho Str., Kyiv, 01001, Ukraine \\ Gobova42@gmail.com
}

In critical moments a nation strives to find support from outside and acquire new allies, especially if the conflict is continuous and not promising a reasonable settlement on the horizon. Among other influential powers on the world stage China has become a desirable partner in more than just trade through the 'peaceful rise' strategy. This paper examines China's image in comparison to the Western allies' and how the idea of 'peaceful rise' resonates with this image among elites in Ukraine and Israel/Palestine. In this paper we argue that the image of 'rising China' in this context is a complex notion which combines antagonistic ideas and is partially contradicting the original strategy of 'peaceful rise'.

Keywords: Ukraine, China, Israel/Palestine, perceptions, conflict

This paper is a small-scale side project based off the "Crisis, Conflict and Critical Diplomacy: EU Perceptions in Ukraine and Israel/Palestine" (C3EU) 3-year research that took place across 9 countries in 2015-2018. The focus of the C3EU project was exclusively on the perceptions of the EU in Ukraine and Israel/Palestine under the European Neighborhood Policy - assessing the effectiveness of EU in conflict resolution, its perceived strengths, range of its messages, distinguishing the key target local audiences that could be the most receptive EU messages etc. At the same time, EU is not the sole actor mentioned throughout the interviews - no matter the region, it was obvious that there was an inclination among the interviewees to at least mention China as one of the most important actors. This prompted a comparison of the images of EU, China and other frequently mentioned actors and an analysis of the context that accompanies the China narrative.

The interviews that were used here were collected in Ukraine, Israel/Palestine, Belgium and Germany, with interviewees belonging to 'elites' in their fields of work (namely media, culture, civil society, business, politics). The questionnaire had neglectable differences in each country, but for the media elites the set of questions had an additional section that was specifically targeted at news-making processes in corresponding countries. However, this discrepancy had no significance for this research. The cases of Ukraine and Israel/Palestine, albeit similar in some aspects of EU perception, are different, but for the objectives of this paper we do not discern between the materials by their origin since they are equally valuable as

(C) 2018 Ye. Hobova; Published by the A. Yu. Krymskyi Institute of Oriental Studies, NAS of Ukraine and the Ukrainian Association of Sinologists on behalf of The Chinese Studies. This is an Open Access article distributed under the terms of the Creative Commons Attribution License (https://creativecommons.org/licenses/by-nc-nd/4.0/). 
substantial evidence of attitudes towards China in conflicted societies. For practical purposes the citations of the interviews that are used here to illustrate the text, are accompanied by indexes that identify their original sources in the general collection of materials, e.g. [Culture, 12, Israel].

The interviews were originally collected in native languages of the speakers, or the languages they chose to speak (Ukrainian, Russian, Hebrew, Arabic, English), which were all later transcribed and translated into English for further use by an international group of researchers. For the sake of this analysis only the final English texts were used, but consultations from native speakers, who had conducted the interviews, were also available.

\section{China's 'Peaceful Rise' in the international relations}

By reviewing the 'Peaceful Rise' strategy and comparing respondents opinions and images of China we make a partial assessment of its efficiency. It is important that none of the interviewees represent a country bordering and having territorial dispute with China or being its major trade partner. This allows us to analyze a more neutral and unbiased point of view, that is not just provided by the percentage numbers in the polls, but is also backed up with verbal descriptions, that help explain what is it that makes China such an important actor.

Over a decade ago China's 'peaceful rise' drew enormous attention from scholars of international relations. When China became world's third largest trade partner in 2004, assessing the benefits and threats of was a major trend in Chinese studies of 2006-2008 and became less While some researchers are quite optimistic about the future of China's 'Peaceful Rise' [Buzan 2010, Foot 2006, Jian 2005, Zhao \& Wang 2014], other find that China's traditional culture and politics may be hindering the grand strategy of integrating hard power and soft power [Wang 2008, Zhang 2011].

One of the more popular ideas among the 'optimists' is that the 'peaceful rise cannot be accomplished by China alone, but only by China and the rest of international society working together to create the necessary conditions' [Buzan 2010, 7]. Peaceful cooperation is paramount to China's current strategy in foreign relations, in which a non-intrusive, non-interfering approach is a major contribution to its image abroad along with the rapid and extensive economic growth.

\section{Images of 'Growing China' and 'European values' in the interviews.}

In the interviews China was frequently mentioned in comparison to other big powers and important regional actors. Several narratives on China were most prominent in the interviews, two of them being predominant: 'the West is in decline and China is growing' and 'China is important in economy but it lacks in values (unlike the EU)'. These two combined create a mixed picture of both an admiration of China's strength and striving for European values. For the interviewees a strong economy does not outweigh the importance of human rights and freedoms, even though the EU itself is being blamed of not fully committing to its declarations. The two less visible supporting narratives are: 'China is neutral in the conflict' and 'we don't know enough about China'. The former is exclusive for Ukrainian interviews, Israel/Palestine interviewees did not mention China as a possible actor in the peacemaking process. This comes from the self-confidence and self-reliance in the field of security that developed in the prolonged conflict, when Ukraine is actively reaching out to potential supporters in attempts to regain its integrity. 
2.1 The EU and the West in general are in decline, while China is growing

EU importance is decreasing, while China's is increasing, often both China and Russia are mentioned as growing in power and ability to influence, as if the world politics is a zero-sum game and one party can only be successful while the other is losing. And the success of China (and some other up-and-coming actors, predominantly Eastern or Asian) is the reason that the EU's importance is lessening or is stagnant at best. The crises in EU are dismissed as not serious or not extensive enough to be a real threat, unlike China that is "on the rise" and almost inadvertently bringing the EU down.

- I think the EU's power is decreasing relative to the power of new powers. It is decreasing because the power of new actors is rising, especially of China. For itself, the EU's power is probably stable. [Culture, 18, Palestine]

- Declining, but not from the inside, despite Brexit it's working is quite stable. Declining because of the rise of other big actors like Russia, China, India, Brazil. [Israel, 12]

China's rise can be an opportunity, that one should be using for own benefit, or a problem to the well-established balance of power in the West.

- Those who manage to import to China have bought themselves financial freedom. [Civil Society 24, Israel]

- It is clear that perhaps, maybe we need to establish or attempt to establish relations with China, because China is becoming a serious player, with the countries of the Group of Seven. [Politics 43 Ukraine]

- How does it [EU] solve problems, for example, globalization, Chinese power and immigration. [Culture, 12, Israel]

This narrative coincides with the predictions of China being 'viewed as the object of hope because of its rapid rise' [Wang 2008, 271]. It partially goes along with the narrative of China being a neutral actor, which will be mentioned later in this paper. It is important that even in the context of conflict, that inevitably shifts the focus away from non-involved actors, China's rise is still recognizable and draws attention.

Many interviewees used terms 'rise', 'rising' and the like to describe China as an emerging superpower, which resonates with the 'China's peaceful rise', that was an official policy under the leadership of Hu Jintao. It was designed to become the antithesis to the popular "Chinese threat" or "yellow threat" narrative. These citations make it clear, that China's rise is seen as both an opportunity and a challenge, but not necessarily a critical threat to a country's stability and wellbeing, rather to the overall proportions of power in world politics.

What is more important, the 'rising China' narrative is comparable to the 'China's peaceful rise' strategy, which has been renamed to or replaced by 'peaceful development' as a less threatening term. Some researchers claim, that this change is only in the name and even propose calling 'peaceful rise 2.0' instead [Jian 2005, 6]. The data from these interviews actually supports this idea - none of the interviewees mentioned 'development', but most of them were using the words 'rise', 'rising' when discussing China. It shows how despite the official rhetoric undergoing adjustments, public opinion retains a more accurate terminology.

2.2 China's importance is almost exclusively economic, but in terms of values it is lagging behind the $\mathrm{EU}$, which is a problem for China itself.

Being an obvious leader in trade and even named the second largest economy in the world, China is expected to be the emerging financial powerhouse, but clearly 
falls behind in other values, that are more typically seen as 'western'. Interviewees tended to mention China as an antithesis of 'West', an undesirable option in the context of values. For these questions there was no prompt that referred to China, unlike some other cases.

- United States and Russia - the US as a financial power, political and cultural power and Russia as a power up against it. China - financial and trade, a potential region for interaction. [Culture, 13, Israel]

- a lot of nice values of course. Freedom, social responsibility, social services, democracy, one type or another, democracy's not perfect you know that. Good standard of living, care for the environment, much more than the Americans and Chinese. In general, a more civilised and cultured way of life. [Civil society, 29, Palestine]

- Palestinian newspapers and their public opinion is irrelevant to me. It's not like they have democracy and can express an opinion. In the same way that I don't perceive Russian Or Chinese newspapers as free press. [Culture, 11, Israel]

- [...] because it is clear that there are no such values as of US, and no values of Russian Federation or China either, but there are European values... [Politics, 50, Ukraine]

- Q: Is sovereignty or human rights a more important principle for deciding how world politics works?

- A: Then definitely, human rights, if we look at current trends, on what is going on in Russia, in Turkey, in China, in Syria. [Civil society, 28, Ukraine]

Mentioning China as a negative example in the context of values without any prompt is indicative both of problems of the international image of China and the issue of lack of information about it, which will be mentioned later in this paper.

2.3 China as a neutral side, as opposed to Russia and EU

China is seen as a desirable ally for Ukraine in terms of politics, but for Israel it is mostly a preferable trade partner. However Ukrainian interviewees are cautious of China's relations with Russia, that may cause undesirable bias and siding with Ukraine's enemy.

- I think that the mediator can not be an interested person. In this conflict, the EU is an interested person. And this is why it happened as it did. If the intermediary was Japan or China... [Business 40 Ukraine]

- That is I would not really want any great friendship with China unless being friends against Russia. [Civil Society 24 Ukraine]

\subsection{Lack of active interest in China, insufficient knowledge}

Some respondents mentioned China as a growing power but confessed not having much knowledge about the current circumstances of that country.

- $[E U]$ is an important player, less than the United States, at some point it was more than Russia, but today it is less then Russia, and about China I don't know enough. [Business, 32, Israel]

- The Chinese are way much more open and do more for cooperation with Ukraine than Ukraine does in response. [Civil society, 25, Ukraine]

Media experts when asked about the focus of international news coverage shifting to some other countries were prompted to make a more elaborate answer by an additional phrase "To the EU? To the US? To China? To Russia? To Turkey? Etc.", hence most of the replies in this section mentioned China specifically. The common 
opinion in this case is that it is not possible for the coverage of that region to increase significantly or at all.

- Being geographically remote and due to some dislike, the USA won't have the same proportion of coverage in Ukrainian mass media. Neither will China, due to the same reason. [Media, 2, Ukraine]

- I don't think that in any... foreseeable [future], - a Ukrainian word does not fit, I can't find any, - future events in China, Africa or America can have so much significance for Ukraine to seriously change the priorities. [Media, 3, Ukraine]

\section{Conclusions}

Main objective of the 'China's peaceful rise' strategy was opposing the 'yellow threat' concept, but as it can be seen from the analysis of the interviews with elites in Ukraine and Israel/Palestine, ironically, the image of China is associated with a threat to the current balance of power in the world, especially to Western countries (the US, countries of European Union etc). For most of the interviewees the world politics is a zero-sum game, where one country can only gain while another one is losing, in this particular case - the EU is losing its power due to other important players becoming more influential. China is named as the most prominent emerging power, but its rise is seen as both admirable and alarming. At the same time, despite the current crises in EU and often complicated relations, in both Ukraine and Israel/Palestine interviews collections EU is still the 'moral compass' to follow - its norms and values are more desirable and accepted, while China is criticized for 'lagging behind'. This indicates a lack of understanding of modern China, and is backed by responses from the media elites, that reveal a scarcity of China news coverage and a low interest in this region from the general audiences. Although obviously mixed and complicated, the image of China in the context of conflicts in Ukraine and Israel/Palestine is largely positive - it is nevertheless a desirable partner and a preferable ally, that could play the role of a neutral third party in the conflict resolution process. This shows efficiency of the strategy, that puts 'peace' as its main message in foreign relations, especially in countries that are in the midst of an ongoing armed conflict. Even though none of the interviewees used the term 'peaceful' or any of its synonyms when mentioning China, the carefully calculated image of a non-intrusive power is definitely reflected in the prevailing narrative of 'a desirable partner'.

\section{REFERENCES}

Buzan B. (2010), China in International Society: Is 'Peaceful Rise' Possible? The Chinese Journal of International Politics. Vol. 3, pp. 5-36.

Foot R. (2006), Chinese Strategies in a US-hegemonic Global Order: accommodating and hedging. International Affairs, 82, I, pp. 77-94.

Gill B., Huang Y. (2006), Sources and limits of Chinese 'soft power'. Survival. Jun 1;48(2), pp. 17-36.

Jian Zhang (2005), China's new foreign policy under Xi Jinping: towards 'Peaceful Rise 2.0'? Global Change, Peace \& Security, 27:1, pp. 5-19.

Li X., Worm V. (2011), Building China's soft power for a peaceful rise. Journal of Chinese Political Science. Mar 1;16(1), pp. 69-89.

Wang Yiwei (2008), Public Diplomacy and the Rise of Chinese Soft Power. Annals, AAPSS, Mar, 616, pp. 257-273. 
Wuthnow J. (2008) The concept of soft power in China's strategic discourse. Issues \& Studies. Jun 1;44(2), pp. 1-28.

Zhang Xiaoming (2011) "A Rising China and the Normative Changes in International Society," East Asia,Vol. 28, No. 3, September, pp. 235-246.

Zhao Huanpu, Wang Zhenling (2014) Meiguo yingdui Zhongguo jueqi: lilun, zhanlüe he hudong. Guoji zhanwang, (3), pp. 4-21.

\section{КИТАЙ ЯК ТРЕТЯ СТОРОНА МИРНОГО ПРОЦЕСУ В УКРАЇНІ ТА ІЗРАЇЛІ/ПАЛЕСТИНІ}

\section{С. В. Гобова}

У критичні моменти країни прагнуть знайти підтримку ззовні та нових союзників, особливо в довготривалих конфліктах, бажане вирішення яких не потребує в найближчому майбутньому. Серед інших великих потуг на світовій арені Китай завдяки своїй стратегії “мирного піднесення” перетворився на бажаного партнера не тільки в торгівлі. У цій статті проаналізовано образ Китаю в порівнянні із західними союзниками та віддзеркалення концепції "мирного зростання" у сприйнятті Китаю серед еліт України та Ізраїлю/Палестини. Образ “Китаю, що зростає” у цьому контексті виявляється неоднозначним та таким, що поєднує суперечливі бачення і частково суперечить первинним положенням стратегії “мирного піднесенню”.

Ключові слова: Україна, Китай, Ізраїль/Палестина, сприйняття, конфлікт

\section{КИТАЙ КАК ТРЕТЬЯ СТОРОНА МИРНОГО ПРОЦЕССА В УКРАИНЕ И ИЗРАИЛЕ/ПАЛЕСТИНЕ}

\section{Е. В. Гобова}

В критические моменты страны стремятся заручиться поддержкой извне и найти новых союзников, особенно в длительных конфликтах, желаемое разрешение которых не предвидится в обозримом будущем. Среди других больших сил на мировой арене Китай благодаря своей стратегии “мирного подъема" превратился в предпочитаемого партнера не только в торговле. В данной статье проанализирован образ Китая относительно западных союзников и отображение концепции "мирного роста" в восприятии Китая среди элит Украины и Израиля/Палестины. Образ "растущего Китая" в данном контексте неоднозначен и сочетает в себе противоречивые видения, а также частично конфликтует с изначальными принципами стратегии "мирного подъема".

Ключевые слова: Украина, Китай, Израиль/Палестина, восприятие, конфликт 